\title{
Level of patients' satisfaction toward National Health Insurance in Istanbul City-Turkey
}

\author{
Saad Ahmed Ali Jadoo ${ }^{1 *}$, Sharifa Ezat Wan Puteh', Zafar Ahmed², Ammar Jawdat ${ }^{1}$ \\ From 6th Postgraduate Forum on Health Systems and Policies \\ Melaka, Malaysia. 21-22 May 2012
}

\section{Background}

Patients' satisfaction is an indirect indicator of patients acceptance towards health management by healthcare providers. Healthcare reform of any magnitude needs to determine their external clients' feedbacks measured through healthcare satisfaction. This study aimed to determine the level of patients' satisfaction and its influencing factors toward the newly reformed national health insurance in Istanbul city, Turkey.

\section{Materials and methods}

A cross sectional study was carried out in July-October 2011. A total of 345 heads of households have been selected by using simple random sampling selection method. Data were collected via household's structured questionnaire and Patients' Satisfaction Questionnaire version II. The response rate was (89\%) and data were analysed by using SPSS version 16.0.

\section{Results}

Age of respondents was around 20 to 70 years old with the mean age of $41.97 \pm 13.87$ years. Majority of clients' had received tertiary education (54.5\%) and most of them were currently employed (87.2\%). Among the respondents, more than half were satisfied toward national health insurance (53.3\%). Respondents were satisfied with domains of access to care $(66.7 \%)$; availability of resources $(52.2 \%)$; technical quality $(56.5 \%)$; overall satisfaction (55.9\%); continuity of care (68.7\%) and humaneness (53.6\%). In bivariate chi-square analysis, eight factors were shown to be significantly associated with level of satisfaction i.e. age, gender, marital status, education, occupation, self-perceived health status, area of residence and type of household's plan. Further analysis, by

'Department of Community Health, Universiti Kebangsaan Malaysia Medical Centre, Jalan Yaacob Latiff, 56000 Kuala Lumpur, Malaysia

Full list of author information is available at the end of the article using multiple logistic regression showed that these eight factors were also significant predictors of satisfaction level.

\section{Conclusion}

This study showed that most of the respondents were satisfied with the existing national health insurance. Higher patients' satisfaction was associated with improved access to care and continuity of care. However, light must be shed on availability of resources, technical quality and humaneness to improve overall patients' satisfaction.

\section{Author details}

'Department of Community Health, Universiti Kebangsaan Malaysia Medical Centre, Jalan Yaacob Latiff, 56000 Kuala Lumpur, Malaysia. ${ }^{2}$ International Training Centre for Case mix and Clinical Coding, Universiti Kebangsaan Malaysia Medical Centre, Jalan Yaacob Latiff, 56000 Kuala Lumpur, Malaysia.

Published: 27 November 2012

doi:10.1186/1471-2458-12-S2-A5

Cite this article as: Ali Jadoo et al: Level of patients' satisfaction toward National Health Insurance in Istanbul City-Turkey. BMC Public Health 2012 12(Suppl 2):A5.

Submit your next manuscript to BioMed Central and take full advantage of:

- Convenient online submission

- Thorough peer review

- No space constraints or color figure charges

- Immediate publication on acceptance

- Inclusion in PubMed, CAS, Scopus and Google Scholar

- Research which is freely available for redistribution

\section{Ciomed Central}

